\title{
Fabrication of Zinc Oxide from Zinc Dust and Its Characterization
}

\author{
Lutfor Rahman ${ }^{1}$, Saiful Quddus ${ }^{2}$, Juliya Khanam², Khadija Bilkis ${ }^{2}$, \\ Moriom Rahman ${ }^{2}$, Nahid Sharmin ${ }^{2}$, AJM Tahuran Neger ${ }^{2}$ \\ Institute of glass and ceramic research and testing, Bangladesh council of scientific and industrial research, \\ Dhaka-1205, Bangladesh
}

\begin{abstract}
Zinc dust, an EPA (Environmental Protection Agency) hazardous waste no. K061 can now be used as a potential raw material for the preparation of zinc zinc oxide. At first zinc was leached from zinc dust in acid medium. The contaminated iron was precipitated out from this solution by oxidation at $\mathrm{pH}$ 3.95-4.05. Then zinc was precipitated from this solution as hydroxide by raising the $\mathrm{pH}$ 6.8-7.2, which on leached with water and filtered followed by two-step drying to produce zinc oxide. The percent purity of the product was found to about 99 and iron contamination in the product was lowered to $50 \mathrm{ppm}$ on Spectrophotometric analysis. It is found that average particle diameter for the prepared sample is $117 \mu \mathrm{m}$ for drying at $140^{\circ} \mathrm{C}$ and $63.6 \mu \mathrm{m}$ for drying at $180^{\circ} \mathrm{C}$. The phase obtained of the prepared sample is zincite and the crystal system was confirmed to be hexagonal by XRD (X-ray diffraction) analysis.
\end{abstract}

Keywords: Zinc-dust, zinc oxide, particle size, XRD, SEM.

\section{Introduction}

The wastage, zinc dust is a by-product of galvanizing industry. It is an EPA listed hazardous waste (KO61). In humans, prolonged excessive exposure to zinc dust can lead to deficiencies in iron \& copper, nausea, fever, headache, tiredness and abdominal pain ${ }^{1}$. Traditionally, this dust has been considered as waste material and used in landfill. But according to Environment Protection Agency regulation, landfill disposal method of zinc dust becomes prohibited because it is classified as hazardous waste based on the toxicity test ${ }^{2}$. Recovery of value added materials from this waste can be economically rewarding as well as reduce environmental pollution. Therefore conversion of this zinc dust to zinc bearing chemicals or oxide or pigments seemed to be a way of using this material. The primary theme of this paper is to recover metal values from zinc dust and convert it to zinc oxide, which has wide applications in various fields. The zinc oxide is used as a reinforced in rubber tires, a white paint pigment, a ceramic glaze, lubricants, ointments, adhesive, sealants, foods, batteries, ferrites, fire retardants, and an opaque base in cosmetics ${ }^{3-4}$. It is also used in catalysis, as adsorbent, for concrete manufacturing, cotton fabrics, food packaging etc ${ }^{5-6}$. Zinc oxide is used to treat a variety of skin condition as baby powder and barrier creams, calamine, anti-dandruff shampoos, and antiseptic ointments $^{7-8}$. It has seen that there are various method exist for preparation of zinc oxide ${ }^{9-15}$. But all these procedures fail to produce high quality zinc oxide. The quality of the product as well as yield depends on a number of parameters. The objective of this study is to prepare pigment grade zinc oxide from zinc dust with hydrochloric acid as leaching agent and ammonium hydroxide as precipitating agent.

\section{II.I Materials}

\section{Experimental}

The raw materials used in this study were zinc dust (collected from a galvanizing industry), hydrochloric acid (commercial grade), hydrogen peroxide (commercial grade) and ammonium hydroxide (commercial grade) which were collected from local market. Other chemicals used were analytical grade eriochrome black $\mathrm{T}$ and thioglycolic acid.

\section{II.II Fabrication of the product}

During fabrication of product, $6 \mathrm{~g}$ zinc dust was allowed to leach with $10 \mathrm{ml}$ conc. $\mathrm{HCl}$ (to make aqueous dilution for getting required concentration) for $15 \mathrm{~min}$. (other fixed parameters such as amount of acid, temperature of reaction period and oxidizing step, time required for oxidation, $\mathrm{pH}$ of solution before oxidizing and during precipitation are achieved by doing several experiments earlier in this laboratory) with constant stirring at $80^{\circ} \mathrm{C}$. It was then filtered to remove un-reacted zinc dust. The $\mathrm{pH}$ of the filtered solution was maintained 3.95-4.05 and oxidized this solution by required amount of hydrogen per oxide (to get desired molar ratio of zinc to oxidizing agent) at $95-100^{\circ} \mathrm{C}$ followed by boiling for 3-5 minutes. Iron was oxidized to ferric oxide and then precipitated which was separated out later. Then $\mathrm{pH}$ of the clear solution was raised to 6.8-7.2 by 
adding required amount of $0.6832 \mathrm{M}$ ammonium hydroxide slowly to precipitate zinc hydroxide. All the soluble impurities of this mass was then leached with water, filtered, dried at $105^{\circ} \mathrm{C}$ and then at $140^{\circ} \mathrm{C}$ to constant weight. Dried mass was then grounded and stored for characterization. A total of 20 samples were prepared by variation of reaction time, concentration of acid, amount of oxidizing agent and precipitating agent.

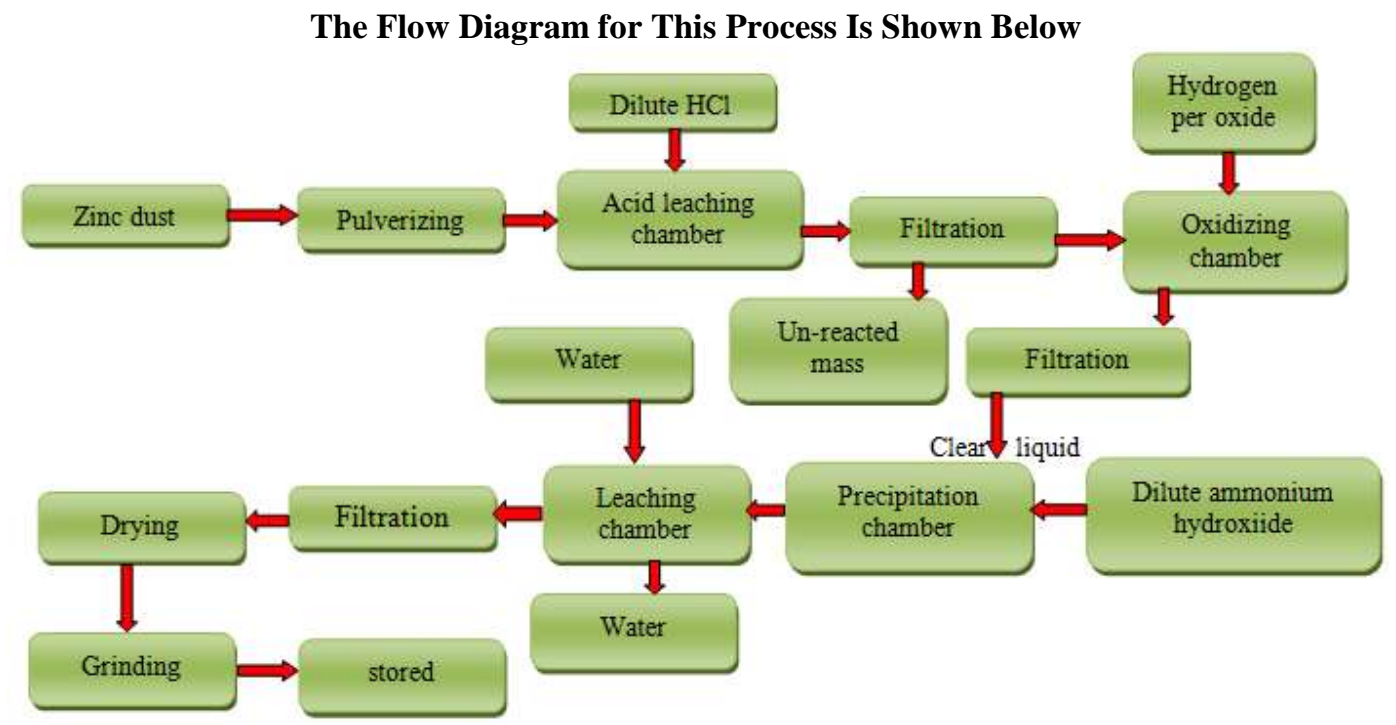

II.III Determination of physical properties

Physical properties like $\mathrm{pH}$ value of aqueous extract ${ }^{16,17}$, sieve residue ${ }^{16-18}$, density ${ }^{16,17}$, loss on ignition ${ }^{16,17}$ and spreadability $^{18}$ of all pigments (both prepared and standard) were determine according to the standard procedures.

II.IV Determination of specific surface area and particle size

Particle size analysis and specific surface area of sample no. 19 were carried out by a particle size analyzer of model Malvern instrument Mastersizer 3000.

\section{II.V X-ray diffraction studies}

The X-ray diffraction pattern of sample no. 19 was recorded by an X-ray diffractometer (model: Bruker D8 advance, $\mathrm{CuK} \alpha$ radiation source $\mathrm{K} \alpha=1.5406 \mathrm{~A}^{\circ}$ ) using $\mathrm{Zr}$ filter and $\mathrm{CuK} \alpha$ radiation. The pattern was obtained between two-theta range of $30-78^{\circ}$ at $30 \mathrm{KV}$ and $20 \mathrm{~mA}$.

\section{II.VI Scanning electron micrographical studies}

Scanning electron micrograph of sample no. 19 was done by a SEM of Model: JEOL, JSM-7610F.

\section{Result and Discussion}

The Chemical analysis of zinc dust and other raw materials such as hydrochloric acid, ammonium hydroxide and hydrogen peroxide used in this study are shown in Table 1.

Table 01: Analysis report on raw materials

\begin{tabular}{|l|c|c|c|c|l|}
\hline Name of raw materials & \multicolumn{2}{|c|}{ Zinc dust } & Hydrochloric acid & Ammonium Hydroxide & Hydrogen peroxide \\
\hline Parameter & $\mathrm{Zn}$ & $\mathrm{Fe}_{2} \mathrm{O}_{3}$ & $\mathrm{HCl}$ & $\mathrm{NH}_{4} \mathrm{OH}$ & $\mathrm{H}_{2} \mathrm{O}_{2}$ \\
\hline Percentage & 96.17 & 0.74 & 32.94 & 30.72 & 27.53 \\
\hline
\end{tabular}

For standardization of the process parameter, four series of experiments were carried out. In the first series, effect of reaction time on the percent yield was studied and depicted on table-02. The experiments were carried out with $1.59 \mathrm{M} 67 \mathrm{ml}$ hydrochloric acid having reaction period of $10 \mathrm{~min}, 15 \mathrm{~min}, 20 \mathrm{~min}$, and $60 \mathrm{~min}$. It is found that amount of reacted zinc dust is increased with the increase of reaction period and maximum reaction takes place at $60 \mathrm{~min}$. But the parameter $15 \mathrm{~min}$ reaction period is more convenient and economical because there is negligible increase $\{(0.0425 \times 100) / 6=0.708 \%\}$ in the reaction mass between these two experiments. The percent yield obtained with 15 min reaction period is around 60 percent though it is not satisfactory. 
Table 02: Effect of reaction time on the yield during the preparation of zinc oxide from zinc dust

\begin{tabular}{|c|c|c|c|c|c|c|c|}
\hline $\begin{array}{l}\text { a } \\
\text { No. of } \\
\text { exp. }\end{array}$ & $\begin{array}{c}\text { b } \\
\text { Reaction } \\
\text { time (min) }\end{array}$ & $\begin{array}{c}\text { c } \\
\text { Unreacted } \\
\text { zinc dust (g) }\end{array}$ & $\begin{array}{c}\text { d } \\
\text { Reacted } \\
\text { zinc dust }(\mathbf{g})\end{array}$ & $\begin{array}{c}\mathrm{e} \\
\text { Reacted zinc in (g) } \\
(\text { d X0.9617) }\end{array}$ & $\begin{array}{c}\mathbf{f} \\
\text { Amount of product } \\
\text { dried at } 105^{\circ} \mathrm{C}\end{array}$ & $\begin{array}{c}\mathrm{g} \\
\text { Amount of product } \\
\text { dried at } 140^{\circ} \mathrm{C}\end{array}$ & $\begin{array}{c}\text { h } \\
\% \\
\text { yield } \\
\end{array}$ \\
\hline 01 & 10 & 1.5369 & 4.4631 & 4.2920 & 4.5248 & 4.0125 & 55.80 \\
\hline 02 & 15 & 1.2230 & 4.7770 & 4.5938 & 4.8425 & 4.2944 & 59.72 \\
\hline 03 & 20 & 1.1858 & 4.8142 & 4.6298 & 4.8800 & 4.3245 & 60.14 \\
\hline 04 & 60 & 1.1805 & 4.8195 & 4.6348 & 4.8861 & 4.3324 & 60.25 \\
\hline
\end{tabular}

Condition: Mode of reaction-closed and stirring, amount of conc. Acid-10 ml., amount of 0.6832M precipitating agent-300 ml

The effect of the molar concentration of hydrochloric acid on the percent yield is shown in table 03 . Here six experiments were carried out with different molar concentration of hydrochloric acid having reaction period $15 \mathrm{~min}$. It was observed that weight of reacted zinc dust increases up to $1.5417 \mathrm{M}$ hydrochloric acid used. Further increase in concentration of hydrochloric acid, reacted zinc mass as well as percent yield decreases. It may be due to the reason that in this series of experiments, the amount of concentrated acid is same but molar concentration is different. At higher molar concentration (more than $1.5417 \mathrm{M}$ ) of acid, zinc could not take part in the reaction properly to produce zinc chloride .

Table 03: Effect of molar concentration of hydrochloric acid on the yield during the preparation of zinc oxide from zinc dust

\begin{tabular}{|c|c|c|c|c|c|c|c|}
\hline $\begin{array}{l}\text { No. of } \\
\text { exp. }\end{array}$ & $\begin{array}{l}\text { Conc. of } \\
\mathrm{HCl}(\mathrm{M})\end{array}$ & $\begin{array}{c}\text { Unreacted zinc } \\
\text { dust (g) }\end{array}$ & $\begin{array}{c}\text { Reacted } \\
\text { zinc dust (g) }\end{array}$ & $\begin{array}{l}\text { Reacted } \\
\text { zinc in }(g)\end{array}$ & $\begin{array}{l}\text { Amount of product } \\
\text { heated at } 110^{\circ} \mathrm{C}\end{array}$ & $\begin{array}{l}\text { Amount of product } \\
\text { heated at } 140^{\circ} \mathrm{C}\end{array}$ & $\begin{array}{c}\% \\
\text { yield }\end{array}$ \\
\hline 05 & 0.5165 & 2.1238 & 3.8762 & 3.7277 & 3.9242 & 3.4761 & 48.34 \\
\hline 06 & 1.0330 & 1.9499 & 4.0501 & 3.8950 & 4.1005 & 3.6230 & 50.39 \\
\hline 07 & 1.5417 & 1.2002 & 4.7798 & 4.5967 & 4.8399 & 4.2893 & 59.65 \\
\hline 08 & 2.0660 & 2.6479 & 3.3521 & 3.2237 & 3.3939 & 3.0090 & 41.86 \\
\hline 09 & 2.5825 & 2.8707 & 3.1293 & 3.0094 & 3.1685 & 2.8090 & 39.01 \\
\hline 10 & 3.1303 & 3.1519 & 2.8481 & 2.7390 & 2.8840 & 2.5573 & 35.55 \\
\hline
\end{tabular}

Condition: Mode of reaction -closed and stirring, amount of conc. Acid-10 ml, reaction time-15 min, amount of $0.6832 \mathrm{M}$ precipitating agent- $300 \mathrm{ml}$

In table 04, effects of molar ratio of iron to oxidizing agent were shown on the removal of iron from the yield. Different molar ratios of iron to hydrogen per oxide were taken in five different experiments to make the soluble iron, insoluble. Thus soluble irons were precipitated out as ferric oxide. Extraction of iron was increases upto1:13.50 molar ratio of iron to hydrogen peroxide treatment which was around 95 percent. More than this molar ratio has no significant effect on the removal of iron.

Table 04: Effect of molar ratio of iron to oxidizing agent on the extraction of iron during the preparation of zinc oxide from zinc dust

\begin{tabular}{|c|c|c|c|c|c|}
\hline $\begin{array}{l}\text { No. of } \\
\text { exp. }\end{array}$ & $\begin{array}{c}\text { Unreacted zinc } \\
\text { dust (g) }\end{array}$ & $\begin{array}{c}\text { Reacted zinc dust } \\
\text { (g) }\end{array}$ & $\begin{array}{c}\text { Molar ratio of iron to } \\
\text { oxidizing agent }\end{array}$ & $\begin{array}{l}\text { Removal of } \\
\mathrm{Fe}_{2} \mathrm{O}_{3}(\mathrm{mg})\end{array}$ & $\begin{array}{c}\% \text { Removal of } \\
\mathrm{Fe}_{2} \mathrm{O}_{3}\end{array}$ \\
\hline 11 & 1.1856 & 4.8144 & $1: 06.66$ & 28.486 & 80.02 \\
\hline 12 & 1.1902 & 4.8098 & $1: 13.50$ & 33.718 & 94.71 \\
\hline 13 & 1.1898 & 4.8102 & $1: 20.17$ & 33.720 & 94.72 \\
\hline 14 & 1.1991 & 4.8129 & $1: 27.00$ & 33.722 & 94.72 \\
\hline 15 & 1.1959 & 4.8081 & $1: 33.66$ & 33.721 & 94.72 \\
\hline
\end{tabular}

N.B. Iron content in the solution was assumed as iron content in the reacted zinc dust

Condition: Mode of reaction-closed and stirring, amount of conc. Acid-10 ml, reaction time- 5 min, amount of $0.6832 \mathrm{M}$ precipitating agent-300 $\mathrm{ml}$

In the next step, soluble zinc content in the clear solution was made insoluble by adding precipitating agent like sodium hydroxide, potassium hydroxide or ammonium hydroxide. In this paper, ammonium hydroxide was used for such purpose. In table 05, effect of molar ratio of zinc to precipitating agent on percent yield was revealed. Here five experiments were done with different molar ratio. It is observed that percent yield was increased with the increase of amount of precipitating agent and found to be highest (around 93\%) with molar ratio 1:3.864 of zinc to precipitating agent. On further increase of molar ratio, has no such impact on percent yield. 
Table 05: Effect of molar ratio of zinc to precipitating agent on the percent yield during the preparation of zinc oxide from zinc dust

\begin{tabular}{|c|c|c|c|c|c|c|c|}
\hline $\begin{array}{c}\text { No. } \\
\text { of } \\
\text { exp. }\end{array}$ & $\begin{array}{l}\text { Molar ratio of zinc to } \\
\text { precipitating agent }\end{array}$ & $\begin{array}{l}\text { Unreacted } \\
\text { zinc dust (g) }\end{array}$ & $\begin{array}{c}\text { Reacted } \\
\text { zinc dust } \\
\quad \text { (g) } \\
\end{array}$ & $\begin{array}{l}\text { Reacted } \\
\text { zinc (g) }\end{array}$ & $\begin{array}{c}\text { Amount of } \\
\text { product heated at } \\
110^{\circ} \mathrm{C} \\
\end{array}$ & $\begin{array}{c}\text { Amount of } \\
\text { product heated at } \\
110^{\circ} \mathrm{C}\end{array}$ & $\%$ Yield \\
\hline 16 & $1: 2.416$ & 1.2051 & 4.7949 & 4.6112 & 3.9515 & 3.7907 & 56.40 \\
\hline 17 & $1: 2.898$ & 1.2011 & 4.7989 & 4.6151 & 4.7333 & 4.5404 & 67.55 \\
\hline 18 & $1: 3.382$ & 1.1998 & 4.8002 & 4.6163 & 5.5319 & 5.3070 & 78.95 \\
\hline 19 & $1: 3.864$ & 1.2034 & 4.7966 & 4.6129 & 6.5744 & 6.0653 & 93.83 \\
\hline 20 & $1: 4.360$ & 1.2040 & 4.7960 & 4.6123 & 6.5940 & 6.1397 & 93.88 \\
\hline
\end{tabular}

Condition: Mode of reaction-closed and stirring, amount of conc. Acid-10 ml, reaction time-5 min, amount of $0.6832 \mathrm{M}$ precipitating agent-300 $\mathrm{ml}$

Some important technical data on zinc oxide are given in table 06. It was seen that the percentage of zinc is somewhat lower than standard sample and theoretical value. It may be due to the reason that the total prepared sample contains nearly 4 percent moisture. Iron content in all these samples is negligible and similar to the standard sample. The entire prepared samples have high loss on ignition compared to standard sample. The reason is same as stated for percentage of zinc. All other values like density and sieve residue are identical and compared to the reported value for standard sample. All the samples are neutral and in acid range. Few of these prepared samples have excellent color hue. They have good spreadability

Table 06: Technical data on zinc oxide

\begin{tabular}{|c|c|c|c|c|c|c|c|c|c|}
\hline $\begin{array}{c}\text { Sample } \\
\text { No. }\end{array}$ & Zn \% & $\mathrm{Fe}_{2} \mathrm{O}_{3}$ & $\begin{array}{c}\text { Moisture } \\
\%\end{array}$ & $\begin{array}{c}\text { Loss on } \\
\text { ignition \% }\end{array}$ & $\begin{array}{l}\text { Density } \\
\text { g/mL }\end{array}$ & pH value & $\begin{array}{l}\text { Sieve residue on } \\
\text { ASTM } 230 \text { sieve }\end{array}$ & $\begin{array}{c}\text { Color } \\
\text { hue }\end{array}$ & $\begin{array}{c}\text { Spread } \\
\text { ability }\end{array}$ \\
\hline 01 & 73.52 & 0.0052 & 4.221 & 8.381 & 4.971 & 6.27 & 0.033 & B W & Good \\
\hline 02 & 73.50 & 0.0049 & 4.239 & 8.399 & 4.976 & 6.08 & 0.018 & B W & Good \\
\hline 03 & 73.51 & 0.0063 & 4.227 & 8.389 & 4.983 & 6.22 & 0.011 & B W & Good \\
\hline 04 & 73.51 & 0.0057 & 4.259 & 8.389 & 4.972 & 6.38 & 0.015 & B W & Good \\
\hline 05 & 73.60 & 0.0048 & 4.242 & 8.277 & 4.990 & 6.41 & 0.002 & B W & Good \\
\hline 06 & 73.81 & 0.0060 & 4.235 & 8.018 & 4.973 & 6.35 & 0.016 & B W & Good \\
\hline 07 & 73.64 & 0.0066 & 4.228 & 8.229 & 4.981 & 6.33 & 0.003 & B W & Good \\
\hline 08 & 73.51 & 0.0047 & 4.243 & 8.391 & 4.969 & 6.40 & 0.035 & B W & Good \\
\hline 09 & 73.65 & 0.0058 & 4.227 & 8.219 & 4.962 & 6.39 & 0.019 & B W & Good \\
\hline 10 & 73.51 & 0.0061 & 4.244 & 8.388 & 4.978 & 6.28 & 0.006 & $\mathrm{M} \mathrm{W}$ & Good \\
\hline 16 & 73.59 & 0.0002 & 4.243 & 8.297 & 4.983 & 6.36 & 0.028 & B W & Good \\
\hline 17 & 73.58 & 0.0050 & 4.250 & 8.301 & 4.974 & 6.42 & 0.029 & B W & Good \\
\hline 18 & 73.53 & 0.0100 & 4.239 & 8.370 & 4.982 & 6.40 & 0.022 & B W & Good \\
\hline 19 & 73.51 & 0.0130 & 4.208 & 8.395 & 4.969 & 6.43 & 0.002 & B W & Good \\
\hline 20 & 73.49 & 0.0101 & 4.229 & 8.379 & 4.980 & 6.41 & 0.009 & B W & Good \\
\hline SS & 79.77 & 0.0020 & 0.200 & 4.412 & 5.00 & 6.01 & 0.02 & B W & Good \\
\hline
\end{tabular}

SS-Standard sample, BW-Bright white, MW-Milky white

Fig-1(a) and Fig-1(b) represent the X-ray diffraction pattern of sample no. 19 dried at $140^{\circ} \mathrm{C}$ and $180^{\circ} \mathrm{C}$ respectively and Fig-1(c) represents the reference sample collected from local market of grade E. Merck, Germany. The position of the peaks as well as the diffraction lines of all these patterns are matched very well

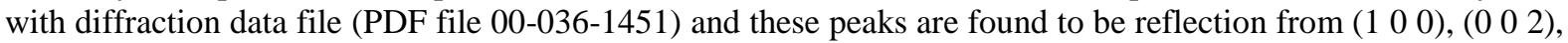

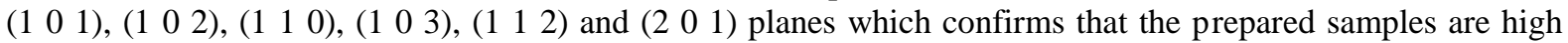
purity zinc oxide, having crystal structure hexagonal. With the experimentally obtained diffraction values, the lattice parameters are $a=3.24982, b=3.24982, c=5.20661, \alpha=\beta=90, \gamma=120$. Though the pattern of Fig-1(a) is not so sharp as Fig-1(b), which is due to the reason that prepared sample contains remarkable amount of moisture in the sample dried at $140^{\circ} \mathrm{C}$. From the XRD analysis, it can be noted that the prepared sample is high purity zinc oxide, shows only zincite phase with space group p63mc, primitive lattice and having calculated molecular weight 81.38 .

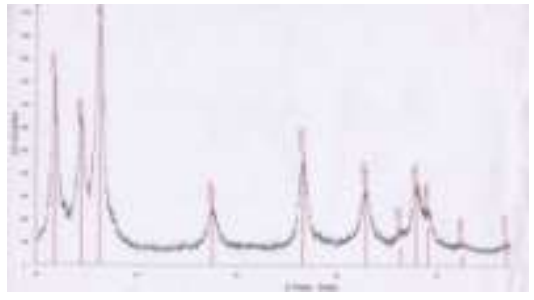

Fig-1(a): $\mathrm{ZnO}$ dried at $140^{\circ} \mathrm{C}$

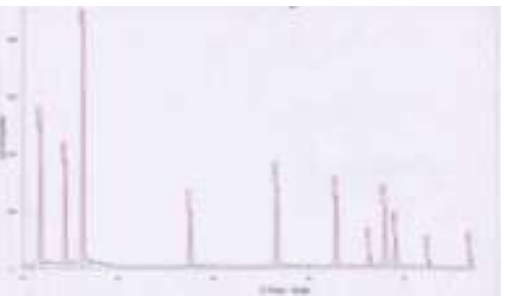

Fig-1(b): $\mathrm{ZnO}$ dried at $180^{\circ} \mathrm{C}$

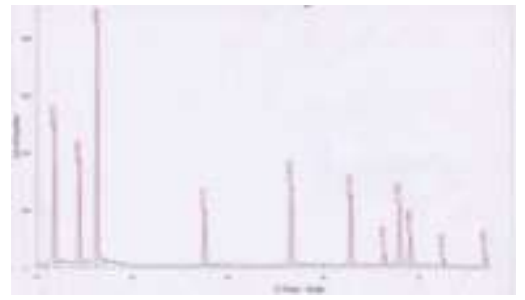

Fig-1(c): Standard ZnO 
Fig-2(a) and Fig-2(b) shows the particle size distribution of sample 19 dried at $140^{\circ} \mathrm{C}$ and $180^{\circ} \mathrm{C}$ respectively. From these two figure it can be noted that Fig-2(a) posses highest peak in the region $62.76 \mu \mathrm{m}$ where as Fig-2(b) posses highest peak in the region $13.56 \mu \mathrm{m}$ which indicates that particle size of the prepared sample reduces on heating and confirms the XRD analysis report. The specific surface area of the sample dried at $140^{\circ} \mathrm{C}$ is $120.8 \mathrm{~m}^{2} / \mathrm{Kg}$ where as $246.9 \mathrm{~m}^{2} / \mathrm{Kg}$ for the sample dried at $180^{\circ} \mathrm{C}$.

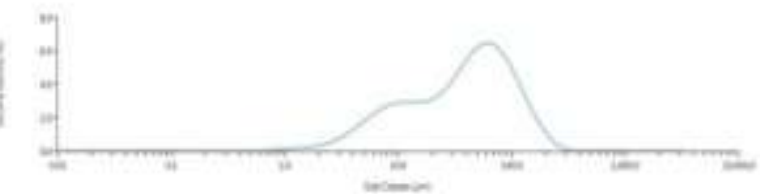

Fig-2(a): Particle size distribution of $\mathrm{ZnO}$ dried at $140^{\circ} \mathrm{C} \quad$ Fig-2(b): Particle size distribution of $\mathrm{ZnO}$ dried at $180^{\circ} \mathrm{C}$

Table 07: Particle size analysis report of the samples

\begin{tabular}{|l|l|l|l|}
\hline Sample name & $\mathbf{1 0 \%}$ particles diameter & $\mathbf{5 0 \%}$ particles diameter & $\mathbf{9 0 \%}$ particles diameter \\
\hline Sample dried at $140^{\circ} \mathrm{C}$ & $\leq 6.50 \mu \mathrm{m}$ & $\leq 48.8 \mu \mathrm{m}$ & $\leq 117 \mu \mathrm{m}$ \\
\hline Sample dried at $180^{\circ} \mathrm{C}$ & $\leq 3.24 \mu \mathrm{m}$ & $\leq 15.8 \mu \mathrm{m}$ & $\leq 63.6 \mu \mathrm{m}$ \\
\hline
\end{tabular}

Fig. 3(a) \& (b) are the Scanning Electron Microscopy image of the prepared sample 19 dried at $140^{\circ} \mathrm{C}$ and $180^{\circ} \mathrm{C}$ respectively with 1500 times magnification at $15 \mathrm{KV}$. It is found that the particles are not uniform in size which supports the above particle size distribution curve. It is clearly noted from Fig-3(a) that particles of the product dried at $140^{\circ} \mathrm{C}$ are agglomerated among themselves whereas Fig-3(b) shows definite particle shape.

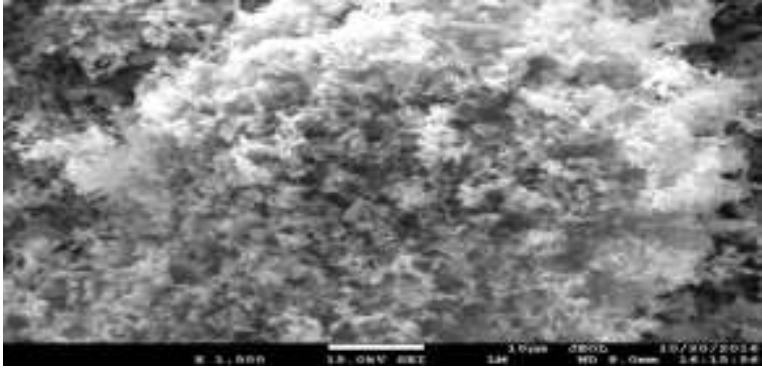

Fig-3(a): SEM image of $\mathrm{ZnO}$ dried at $140^{\circ} \mathrm{C}$

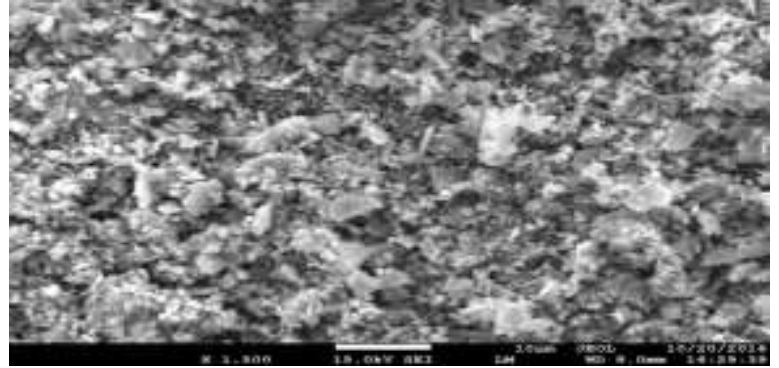

Fig-3(b) SEM image of $\mathrm{ZnO}$ dried at $180^{\circ} \mathrm{C}$

\section{Conclusion}

Zinc oxide can be prepared by leaching with 1.5417M hydrochloric acid for 15 minute followed by purifying the resulting clear solution from iron which on precipitation at $\mathrm{pH}$ 6.8-7.2 produces zinc oxide. On spectrophotometric analysis, it is found that the final product has percent purity around 99. On XRD analysis, it is found that the prepared sample has zincite phase with hexagonal structure and independent lattice parameters are $\mathrm{a}=\mathrm{b}=3.24950$ and $\mathrm{c}=5.20690$. The average particle diameter of the prepared sample is of $117 \mu \mathrm{m}$ for drying at $140^{\circ} \mathrm{C}$ and $63.6 \mu \mathrm{m}$ for drying at $180^{\circ} \mathrm{C}$. Thus, the present study may therefore serve as a guideline for preparation of zinc oxide and may also be seen as general review for pigment chemistry and pigment technology.

\section{Acknowledgements}

The authors express their heartfelt thanks to Dr. Md. Abdul Gafur and Md.Rakibul Qadir Bangladesh council of scientific and industrial Research, Dhaka-1205, Bangladesh

\section{References}

[1]. R.J. Irwin, M.V.Mouwerik, L. Stevens , M.D. Seese, , W. Basham, Environmental contaminants encyclopedia. National Park Service, Water Resources Division, Fort Collins, Colorado, 1997.

[2]. U.S. Patent no. 6,863,873 B1.

[3]. N. Alane, S. Djerad and L. Tifouti “Acid Leaching of Zinc Oxide from $\mathrm{ZnO} / \mathrm{Al}_{2} \mathrm{O}_{3}$ Catalyst” Lebanese Science Journal, Vol. 9, No. 2, 2008, 63 .

[4]. A. Hernandezbattez, R.Gonzalez, J. Viesca, J. Fernandez, J. Diazfernandez, A. MacHado, R. Chou, J. Riba. "CuO, ZrO 2 and ZnO nanoparticles as antiwear additive in oil lubricants". Wear 265: 2008, 422.

[5]. J.C. Chen, C.T. Tang, "Preparation and application of granular $\mathrm{ZnO} / \mathrm{Al}_{2} \mathrm{O}_{3}$ catalyst for the removal of hazardous trichloroethylene". J. Hazard. Mater., 2007, 8-96 (142). 
[6]. M. Saito. "Antibacterial, Deodorizing, and UV Absorbing Materials Obtained with Zinc Oxide (ZnO) Coated Fabrics". Journal of Industrial Textiles 23, 1993, 150.

[7]. Harding, F. John, Brest cancer:cause-prevention-cure, Tekline Publishing, 2007, 83.

[8]. British national formulary : barrier preparations, Sections 13.2.2, 2008.

[9]. U.S. Patent no. 3897248

[10]. U.S. Patent no. 1863700

[11]. U.S. Patent no. 5028410

[12]. U.S. Patent no. 2007/0172415 Al

[13]. U.S. Patent no. 6726889 B2

[14]. U.S. Patent no. 6361753 B1

[15]. U.S. Patent no. 6863873 B1

[16]. B. Elvers, S. Hawkins, G. Schulz, Ullmann's encyclopedia of industrial chemistry, Vol. A20, $5^{\text {th }}$ edition (VCH publishers, Inc. 1992) 255- 257

[17]. Inorganic pigments for the coatings industry (Bayer)

[18]. Chapman \& Hall, Paint technology manuals, part six, pigments dyestuffs and lakes (London, Oil \& Colour Chemists' Association , 1966) 17,90 